\title{
Detection of serum antibodies to Brucella in Russian aquatic mammals
}

\author{
Kazue OHISHI ${ }^{1) *}$, Erika ABE ${ }^{1)}$, Masao AMANO ${ }^{2)}$, Nobuyuki MIYAZAKI ${ }^{3,4)}$, \\ Andrei BOLTUNOV ${ }^{5)}$, Etsuko KATSUMATA ${ }^{6)}$ and Tadashi MARUYAMA ${ }^{1)}$
1)Japan Agency for Marine-Earth Science and Technology (JAMSTEC), 2-15 Natsushima-cho, Yokosuka, Kanagawa 237-0061, Japan
${ }^{2)}$ Graduate School of Fisheries and Environmental Sciences, Nagasaki University, 1-14 Bunkyo-machi, Nagasaki 852-8521, Japan
${ }^{3)}$ Atmosphere and Ocean Research Institute, The University of Tokyo, 5-1-5 Kashiwa, Chiba 277-8564, Japan
4)Japan Marine Science Foundation, 1-1-1 Ikenohata, Taito-ku, Tokyo 110-0008, Japan
${ }^{5)}$ Marine Mammal Research and Expedition Center, Moscow 115551, Russia
${ }^{6)}$ Kamogawa Sea World, Kamogawa, Chiba 296-0041, Japan

\section{J. Vet. Med. Sci. \\ 80(11): 1696-1701, 2018}

doi: 10.1292/jvms.18-0330

Received: 17 June 2018

Accepted: 26 August 2018

Published online in J-STAGE:

5 September 2018

\begin{abstract}
A serologic survey of Brucella infection was performed in Caspian seals (Pusa caspica, $\mathrm{n}=71$ ), Baikal seals ( . sibirica, $\mathrm{n}=7$ ), ringed seals ( . hispida hispida, $\mathrm{n}=6$ ), and beluga whales (Delphinapterus leucas, $\mathrm{n}=4$ ) inhabiting Russian waters, by enzyme-linked immunosorbent assay (ELISA) using Brucella abortus and B. canis as antigens. The sera of 4 Caspian seals (4\%) tested positive for $B$. abortus. The same sera samples demonstrated weaker yet detectable affinity for $B$. canis antigens. Several discrete bands against $B$. abortus and $B$. canis antigens were detected on Western blot analysis of the ELISA-positive seal sera; the bands against $B$. canis were weaker than those against $B$. abortus. The sera of 3 beluga whales (75\%) were positive for $B$. abortus antigens but showed no binding to $B$. canis antigens in the ELISA. The positive whale sera showed a strong band appearance only against $B$. abortus antigens in the Western blot analysis. Many detected bands were discrete, while some of them had a smeared appearance. The present results indicate that Brucella infection occurred in Caspian seals and beluga whales inhabiting Russian waters, and that the Brucella strains infecting the seals and the whales were antigenetically distinct.

KEY WORDS: antibody, Baikal seal, beluga whale, Brucella, Caspian seal
\end{abstract}




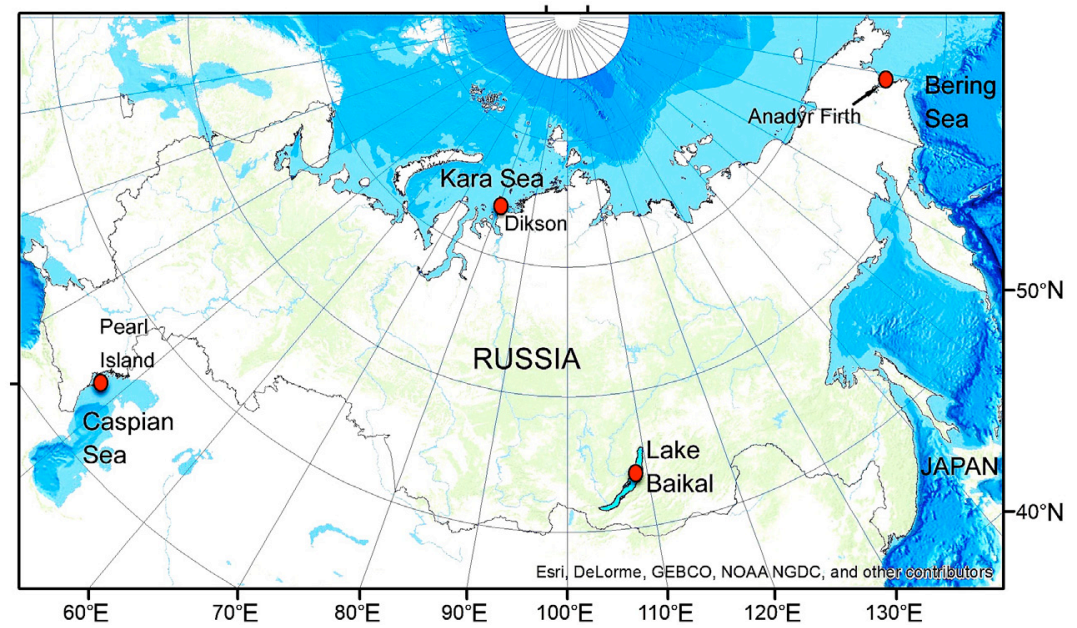

Fig. 1. Sampling sites included in the study.

\section{MATERIALS AND METHODS}

\section{Samples}

We have conducted the Russian-Japanese Joint Research Program for Biological and Environmental Studies with the permission from the Russian Federation and the local governments. This study was performed in accordance with the guidelines of the Animal Ethic Committee of the University of Tokyo. Sera samples from Caspian seals were obtained on the Pearl Island (Fig. 1; 45 03 ' $\mathrm{N}, 48^{\circ} 18^{\prime}$ E) located in the north-west area of the Caspian Sea, between November 5-11, 1993; August 15-16, 1997; September 12-16, 1998; and September 24-October 8, 2000. Sera samples from 7 Baikal seals in the Lake Baikal (Fig. 1; 53 46’-52' N, 108 23'-31' E) were collected on May 21 and 22, 1998. The sera of six ringed seals were obtained at Dickson in the southern part of the Kara Sea from May 2 to 22, 2002 (Fig. 1; 733' $\mathrm{N}, 80^{\circ} 31^{\prime}$ E). The ages of Caspian seals and ringed seals were estimated by counting the growth layers in both the dentine and cementum of the canine [4]. The 3 species of seals were all subjected to gross pathological observation. Sera from 4 beluga whales were collected at Anadyr Firth on July 20, 2001 (Fig. 1; 64 83' N, 176 ${ }^{\circ} 72^{\prime}$ E). The life stage of the beluga whales was estimated based on their body length [30].

\section{Enzyme-linked immunosorbent assay}

Anti-Brucella serum antibody was detected in the enzyme-linked immunosorbent assay (ELISA) according to the protocol described previously [1]. Briefly, commercially available inactivated B. abortus strain 125 (Kaketsuken Co., Kumamoto, Japan) and B. canis strain QE-13B (Kitasato Institute Co., Tokyo, Japan) were solubilized and absorbed to the inner surface of each well $(50 \mu \mathrm{g} / 50 \mu \mathrm{l} /$ well $)$ of a 96-well microtiter plate. The sera diluted at 1:100 were used as the primary antibody, and horseradish peroxidase-conjugated Protein A/G (Thermo Fisher Scientific Inc., Waltham, MA, U.S.A.) diluted at 1:5,000 was used for detection. The absorbance at $405 \mathrm{~nm}$ was measured and the arithmetic mean of triplicate absorbance data points with the standard deviation (SD) was calculated. Serum samples showing the absorbance value higher than 0.2 against B. abortus, were regarded as positive, based on the values of serum samples from captive animals [1].

\section{Western blot analysis}

Western blot analysis was performed according to the method described previously [36]. Proteins of the solubilized B. abortus strain 125 and $B$. canis strain QE-13B were respectively separated on a 10\% polyacrylamide gel by SDS polyacrylamide gel electrophoresis (20 $\mu \mathrm{g} / \mathrm{lane})$ and blotted onto a polyvinylidene difluoride membrane (Millipore Co., Billerica, MA, U.S.A.). Serum samples diluted to 1:100 were used as the first antibodies, and then horseradish peroxidase-conjugated Protein-A/G (Thermo Fisher Scientific Inc.) diluted to 1:5,000 was used for detection.

\section{RESULTS}

\section{Anti-Brucella antibodies assessed by ELISA}

All serum samples were examined for antibodies against B. abortus and B. canis antigens by ELISA. Some samples from Caspian seals and beluga whales showed a value higher than 0.2 only for B. abortus antigens (Table 1). The sera of 4 among the examined 71 Caspian seals showed positive absorbance for B. abortus antigens (OD at $405 \mathrm{~nm}$ : 0.22-0.26) (Table 1). The absorbance for $B$. canis antigens in the same samples ranged from $0.12-0.19$, which was relatively higher than that of other sera samples, though lower than 0.2 threshold. The age of the Caspian seals, estimated by counting the canine layers, ranged widely from less than 1 to 32 years. The 4 ELISA-positive Caspian seals were estimated to be adults at 11.5-31.5 years of age, based on 
Table 1. Prevalence of serum antibodies against B. abortus in Caspian seals, Baikal seals, ringed seals and beluga whales

\begin{tabular}{lcccc}
\hline \multirow{2}{*}{ Species } & \multirow{2}{*}{ Year } & \multicolumn{3}{c}{ Positive rate to B. abortus $^{\text {a) }}$} \\
\cline { 3 - 5 } & & Male & Female & Total (\%) \\
\hline Caspian seal (Pusa caspica) & 1993 & $0 / 9$ & $0 / 3$ & $0 / 12$ \\
& 1997 & $1 / 4$ & $0 / 3$ & $1 / 7(14)$ \\
& 1998 & $0 / 3$ & $1 / 12$ & $1 / 15(7)$ \\
& 2000 & $2 / 14$ & $0 / 23$ & $2 / 37(5)$ \\
& Total & $3 / 30$ & $1 / 41$ & $4 / 71(6)$ \\
\hline Baikal seal (Pusa sibirica) & 1998 & $0 / 6$ & $0 / 1$ & $0 / 7$ \\
Ringed seal (Pusa hispida hispida) & 2002 & $0 / 3$ & $0 / 3$ & $0 / 6$ \\
Beluga whale (Delphinapterus leucas) & 2001 & $1 / 1$ & $2 / 3$ & $3 / 4(75)$ \\
\hline
\end{tabular}

a) Absorbance greater than 0.2 at $405 \mathrm{~nm}$ in ELISA is regarded as positive.

(a)

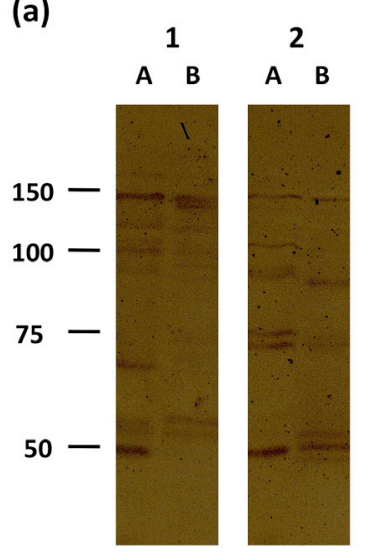

(b)

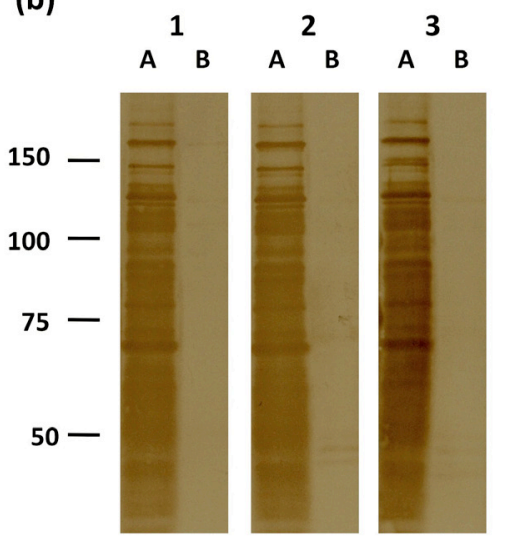

Fig. 2. Western blot analysis of the serum from ELISA-positive Caspian seals and beluga whales against B. abortus and B. canis antigens. (a), Caspian seals: Lane 1, sample ID, 98C46; and Lane 2, ID, 00C17. (b) Beluga whales: Lane 1, ID, No.1; Lane 2, ID, No. 10; and Lane 3, ID, No. 11. A, B. abortus antigen. B, B. canis antigen.

previous data [15].

The sera of 3 out of the 4 examined Beluga whales also demonstrated positive absorbance against $B$. abortus antigens (Table 1). Based on the body length, 2 of the examined whales appeared to be adults $(395$ and $350 \mathrm{~cm})$ and the other 2 were juveniles $(318$ and $302 \mathrm{~cm}$ ) [30]. One of the ELISA-positive whales was an adult and 2 were juveniles. The serum sample of the juvenile female whale showed high absorbance (OD at $405 \mathrm{~nm}=0.72$ ), and that of the other 2 demonstrated lower absorbance (OD at $405 \mathrm{~nm}=0.26$ and 0.27 ). No serum sample from the 4 examined whales reacted with $B$. canis antigens (OD at $405 \mathrm{~nm}=0.04-0.06$ ).

\section{Western blot analysis for antibody specificity against B. abortus and B. canis}

Since ELISA showed differences in antibody reactivity to $B$. abortus and B. canis in the antibody-positive serum samples between Caspian seals and beluga whales, the antigen specificity was further examined by Western blot using 2 available Caspian seal serum samples and all 4 beluga whale serum samples. The 2 Caspian seal sera (Serum ID: 98C46 and 00C17) previously showed the lowest absorbance in ELISA (OD at $405 \mathrm{~nm}$ : 0.22) out of the 4 positive serum samples. In Western blot analysis, they displayed similar band patterns: some weak yet sharp bands were formed as a response to both antigens of $B$. abortus and B. canis (Fig. 2a). The Western blot bands appeared to be slightly denser in case of $B$. abortus compared to B. canis antigens.

The Western blot band patterns of the 3 ELISA-positive serum samples from beluga whales (Serum ID: No. 1, No. 10 and No. 11) were similar to each other. Many bands, including the smeary bands, were detected in B. abortus Western blots while none were observed in case of $B$. canis (Fig. 2b). Western blot was also applied to the negative seal sera showing the absorbance close to the significance threshold of 0.2 (OD at $405 \mathrm{~nm}: 0.15-0.16$ ) and 1 negative beluga whale serum (OD at $405 \mathrm{~nm}: 0.13$ ), but no bands were observed (data not shown).

\section{DISCUSSION}

The present serologic study demonstrated that Brucella infection occurred in Caspian seal and beluga whale populations inhabiting Russian waters. The presence of anti-Brucella antibodies in Caspian seals is consistent with the findings in the previous 
report [9]. As Caspian seal pups are born from the middle of January to the middle of February [15], the examined yearling seals $(\mathrm{n}=16)$ in this study were estimated to be approximately 6-10 months old at the time of sampling. All of them were Brucellaantibody negative; however, the absence of anti-Brucella antibodies in these seals is not likely to be a result of immaturity of the acquired immunity, because the production of influenza virus antibodies in these yearlings was detected in our earlier research [31]. The age-dependent serological pattern of anti-Brucella antibodies has been reported in hooded seals (Cystophora cristata) in the North Atlantic population and the Eastern Pacific harbor seals ( $P$. vitulina richardsi) [22, 28]. These studies show that yearling seals have a higher percentage of antibodies than pups or older seals. This may indicate that they were environmentally exposed to Brucella at the juvenile stage, which subsequently cleared in the later stages, as suggested by Nymo et al. [28]. It has been reported that $B$. pinnipedialis strains infecting hooded seal multiply neither in the seal macrophages nor epithelial cells, suggesting the absence of chronic infection in hooded seals $[23,24]$. The present serologic data is, however, inconsistent with the age-dependency. The adult seals might have been infected at the early stage of life when Brucella spp. were epidemic in the past, and the infection might still persist in their later lives. Alternatively, the antibody-positive adult Caspian seals might be infected at an adult stage by a different transmission route in the hooded seals and harbor seals. To clarify how the Brucella spp. are transmitted in the Caspian seal populations and whether the infection persists, the Brucella must be isolated from Caspian seals and characterized in a future study. We found some females with a trace of abortion; however, they were Brucella antibody-negative. A previous study has shown that B. pinnipedialis was isolated from lungworms [14]. Although we observed a nematode infection in the lungs of several Caspian seals in the 2000 survey [31], there was no apparent relation between the histopathological observation of the parasites and anti-Brucella antibody positivity.

Anti-Brucella antibodies were not detected in the sera of the 7 examined Baikal seals, which is consistent with findings in earlier research [37]. All the Baikal seals were judged to be less than 1 year old based on their body length (85-103 cm) [26]. As Baikal seals deliver pups in February [26], the juveniles were estimated to be only 3 months old at the time of sampling. They seemed to be independent from their mothers. The lack of the specific antibody is likely not due to the immaturity of the immune system with impaired ability to produce antibodies, since previously we were able to detect specific antibodies to influenza virus in these animals [33]. Likewise, no anti-Brucella antibodies were detected in ringed seals in the present study. The age of the ringed seals ranged between 6-27 years, and all were thought to be adults [17]. Anti-Brucella antibodies were reported in the same subspecies Pusa hispida hispida inhabiting the North Atlantic, the west of Svalbard island and Baffin Island in the Arctic, and the Alaskan waters $[12,27,29,41]$. As the sample size in the present study is very small, further survey is necessary to establish the distribution of Brucella in this species.

The beluga whales inhabiting the Anadyr Firth showed a high prevalence of the antibody, and 1 serum sample showed a strong antibody response. Anti-Brucella antibodies were previously found in beluga whales inhabiting Arctic Canada [27]. The Anadyr Firth is geographically connected to the Arctic Sea and the western North Pacific. Little data is available with regard to Brucella infection in the western North Pacific; however, we have previously shown that the infection occurred in 3 species of baleen whales and sperm whales based on a long-term and large-scale serologic study in the sea area [36]. The DNA analysis indicated that these Brucella were different from the typical B. ceti prevalent in European and American waters [34, 35]. Detailed DNA analysis of Brucella in the western North Pacific and the waters connected to the Arctic may provide valuable insight into the distribution of Brucella at a global level and the evolution of the bacteria.

The present ELISA and Western blot analyses indicated that the Brucella antigen in Caspian seals was different from that in beluga whales (Fig. 2). With regard to antigenicity, the types of Brucella detected in Caspian seals and beluga whales were more similar to B. abortus than B. canis. Further, compared to the seal Brucella, the beluga whale Brucella seemed to be more distant from B. canis. The presence of smeared bands might demonstrate that the beluga whale Brucella was a smooth colony (S) type possessing lipopolysaccharide (LPS) containing O-type polysaccharide (O-PS) in the outer membrane, as well as, $B$. melitensis, $B$. suis, B. neotome, and B. ceti [43]. On the other hand, the Caspian seal Brucella might be a rough colony (R) type that possesses LPS without O-PS, as well as, B. canis.

While Brucella species are known to preferentially infect their respective host mammalians, California sea lions (Zalophus californianus) were reported to be infected with terrestrial Brucella [5]. As Baikal seals and Caspian seals dwell in a land-locked aquatic area, they have a higher risk for the transmission of infectious agents from terrestrial animals, such as canine distemper virus - a causative agent of the mass-die-off of these seals [7]. Moreover, the reports of novel Brucella species are accumulating in animals other than mammals, such as fish and frogs $[2,10,18,21]$ and in the soil [39]. We may have to consider the possibility of interspecies transmission of Brucella in a greatly vast Russian Eurasia Continent, populated by various terrestrial and marine animals that form a huge ecosystem.

Recent global warming is bringing out an environmental change affecting animal distribution, especially the melting of ice in the Arctic sea. It may cause a critical ecological influence on the animals in the Arctic sea and the connecting North Asian waters including Anadyr Firth. We must not only continue the serologic survey of the inhabiting mammals but also accelerate the isolation and characterization of Brucella from them. In addition, pathological studies including reproductive disorders are warranted, although the evidence of abnormality of reproduction in seals and whales were not observed in the present study. These studies would contribute to the conservation of wild animals and their ecosystems.

ACKNOWLEDGMENTS. The authors would like to thank the following persons for their support: Dr. E. A. Petrov of Limunological Institute, Russia, Dr. L. S. Khuraskin and Dr. N. A. Zakharova of Caspian Fisheries Research Institute, Russia, Dr. S. Belikov of All-Russian Research for Nature Protection, Russia, Mr. Mikhail Krohin of Pavlovskaya Sloboda Ltd., Russia, Prof. K. Numachi, 
Dr. T. Arai, Mr. T. Kosaka and Mr. Y. Takada of Atmosphere and Ocean Research Institute, The University Tokyo, Japan, and Prof. S. Tanabe and Dr. H. Nakata of Ehime University, Japan. This research was partially supported by a grant-in-aid from International Scientific Research Program of Japan Society for the Promotion of Science (Project Nos. 04041035, 07041130, 09041149).

\section{REFERENCES}

1. Abe, E., Ohishi, K., Ishinazaka, T., Fujii, K. and Maruyama, T. 2017. Serologic evidence of Brucella infection in pinnipeds along the coast of Hokkaido, the northernmost main island of Japan. Microbiol. Immunol. 61: 114-122. [Medline] [CrossRef]

2. Al Dahouk, S., Köhler, S., Occhialini, A., Jiménez de Bagüés, M. P., Hammerl, J. A., Eisenberg, T., Vergnaud, G., Cloeckaert, A., Zygmunt, M. S., Whatmore, A. M., Melzer, F., Drees, K. P., Foster, J. T., Wattam, A. R. and Scholz, H. C. 2017. Brucella spp. of amphibians comprise genomically diverse motile strains competent for replication in macrophages and survival in mammalian hosts. Sci. Rep. 7: 44420. [Medline] [CrossRef]

3. Amano, M., Koyama, Y., Petrov, E. A., Hayano, A. and Miyazaki, N. 2000. Morphometric comparison of skulls of seals of the subgenus Pusa. pp. 315-323. In: Lake Baikal (Minoura, K. ed.), Elsevier Press, Amsterdam.

4. Amano, M., Miyazaki, N. and Petrov, E. A. 2000. Age determination and growth of Baikal seals (Phoca sibirica). pp. 449-462. In: Advances in Ecological Research, (Rossiter, A. and Kawanabe, H. eds.), Vol. 31: Ancient Lakes: Biodiversity, Ecology and Evolution. Academic Press, London.

5. Avalos-Téllez, R., Ramírez-Pfeiffer, C., Hernández-Castro, R., Díaz-Aparicio, E., Sánchez-Domínguez, C., Zavala-Norzagaray, A., ArellanoReynoso, B., Suárez-Güemes, F., Aguirre, A. A. and Aurioles-Gamboa, D. 2014. Infection of California sea lions (Zalophus californianus) with terrestrial Brucella spp. Vet. J. 202: 198-200. [Medline] [CrossRef]

6. Corbel, M. J. and Banai, M. B. 2005. Genus Brucella. pp. 370-386. In: Bergey’s Manual of Systematic Bacteriology. Vol. 2. (Brenner, D. J., Kreig, N. R. and Staley, J. T. eds.), Springer Press, New York.

7. Di Guardo, G., Marruchella, G., Agrimi, U. and Kennedy, S. 2005. Morbillivirus infections in aquatic mammals: a brief overview. J. Vet. Med. A Physiol. Pathol. Clin. Med. 52: 88-93. [Medline] [CrossRef]

8. Duncan, C. G., Tiller, R., Mathis, D., Stoddard, R., Kersh, G. J., Dickerson, B. and Gelatt, T. 2014. Brucella placentitis and seroprevalence in northern fur seals (Callorhinus ursinus) of the Pribilof Islands, Alaska. J. Vet. Diagn. Invest. 26: 507-512. [Medline] [CrossRef]

9. Durymanova, A. A., Dimov, S. K., Kuznetsov, V. N., Khuras'kin, L. N., Zolotykh, S. I. and Shestopalov, A. M. 2004. [Antibodies to Brucella in caspian seals]. Zh. Mikrobiol. Epidemiol. Immunobiol. 6: 99-101 (in Russian). [Medline]

10. Eisenberg, T., Riße, K., Schauerte, N., Geiger, C., Blom, J. and Scholz, H. C. 2017. Isolation of a novel 'atypical' Brucella strain from a bluespotted ribbontail ray (Taeniura lymma). Antonie van Leeuwenhoek 110: 221-234. [Medline] [CrossRef]

11. Ewalt, D. R., Payeur, J. B., Martin, B. M., Cummins, D. R. and Miller, W. G. 1994. Characteristics of a Brucella species from a bottlenose dolphin (Tursiops truncatus). J. Vet. Diagn. Invest. 6: 448-452. [Medline] [CrossRef]

12. Forbes, L. B., Nielsen, O., Measures, L. and Ewalt, D. R. 2000. Brucellosis in ringed seals and harp seals from Canada. J. Wildl. Dis. 36: 595-598. [Medline] [CrossRef]

13. Foster, G., Osterman, B. S., Godfroid, J., Jacques, I. and Cloeckaert, A. 2007. Brucella ceti sp. nov. and Brucella pinnipedialis sp. nov. for Brucella strains with cetaceans and seals as their preferred hosts. Int. J. Syst. Evol. Microbiol. 57: 2688-2693. [Medline] [CrossRef]

14. Garner, M. M., Lambourn, D. M., Jeffries, S. J., Hall, P. B., Rhyan, J. C., Ewalt, D. R., Polzin, L. M. and Cheville, N. F. 1997. Evidence of Brucella infection in Parafilaroides lungworms in a Pacific harbor seal (Phoca vitulina richardsi). J. Vet. Diagn. Invest. 9: 298-303. [Medline] [CrossRef]

15. Goodman, S. J. 2017. Caspian seal. pp. 164-166. In: Encyclopedia of Marine Mammals, 3rd ed. (Wursig, B., Thewissen, J. G. M. and Kovacs, M. eds.), Academic Press, San Diego.

16. Guzmán-Verri, C., González-Barrientos, R., Hernández-Mora, G., Morales, J. A., Baquero-Calvo, E., Chaves-Olarte, E. and Moreno, E. 2012. Brucella ceti and brucellosis in cetaceans. Front. Cell. Infect. Microbiol. 2: 3. [Medline] [CrossRef]

17. Hammill, M. O. 2017. Ringed seal. pp. 822-824. In: Encyclopedia of Marine Mammals. 3rd ed. (Wursig, B., Thewissen, J. G. M. and Kovacs, M. eds.), Academic Press, San Diego.

18. Helmick, K. E., Garner, M. M., Rhyan, J. and Bradway, D. 2018. Clinicopathologic features of infection with novel Brucella organisms in captive waxy tree frogs (Phyllomedusa sauvagii) and Colorado river toads (Incilius alvarius). J. Zoo Wildl. Med. 49: 153-161. [Medline] [CrossRef]

19. Hernández-Mora, G., Palacios-Alfaro, J. D. and González-Barrientos, R. 2013. Wildlife reservoirs of brucellosis: Brucella in aquatic environments. Rev. Off. Int. Epizoot. 32: 89-103. [Medline] [CrossRef]

20. Jauniaux, T. P., Brenez, C., Fretin, D., Godfroid, J., Haelters, J., Jacques, T., Kerckhof, F., Mast, J., Sarlet, M. and Coignoul, F. L. 2010. Brucella ceti infection in harbor porpoise (Phocoena phocoena). Emerg. Infect. Dis. 16: 1966-1968. [Medline] [CrossRef]

21. Kimura, M., Une, Y., Suzuki, M., Park, E. S., Imaoka, K. and Morikawa, S. 2017. Isolation of Brucella inopinata-like bacteria from White's and Denny's tree frogs. Vector Borne Zoonotic Dis. 17: 297-302. [Medline] [CrossRef]

22. Lambourn, D. M., Garner, M., Ewalt, D., Raverty, S., Sidor, I., Jeffries, S. J., Rhyan, J. and Gaydos, J. K. 2013. Brucella pinnipedialis infections in Pacific harbor seals (Phoca vitulina richardsi) from Washington State, USA. J. Wildl. Dis. 49: 802-815. [Medline] [CrossRef]

23. Larsen, A. K., Nymo, I. H., Boysen, P., Tryland, M. and Godfroid, J. 2013. Entry and elimination of marine mammal Brucella spp. by hooded seal (Cystophora cristata) alveolar macrophages in vitro. PLoS One 8: e70186. [Medline] [CrossRef]

24. Larsen, A. K., Godfroid, J. and Nymo, I. H. 2016. Brucella pinnipedialis in hooded seal (Cystophora cristata) primary epithelial cells. Acta Vet. Scand. 58: 9. [Medline] [CrossRef]

25. Miller, W. G., Adams, L. G., Ficht, T. A., Cheville, N. F., Payeur, J. P., Harley, D. R., House, C. and Ridgway, S. H. 1999. Brucella-induced abortions and infection in bottlenose dolphins (Tursiops truncatus). J. Zoo Wildl. Med. 30: 100-110. [Medline]

26. Miyazaki, N. 2017. Baikal seal, pp. 57-58. In: Encyclopedia of Marine Mammals, 3rd ed. (Wursig, B., Thewissen, J. G. M. and Kovacs, M. eds.), Academic Press, San Diego.

27. Nielsen, O., Stewart, R. E., Nielsen, K., Measures, L. and Duignan, P. 2001. Serologic survey of Brucella spp. antibodies in some marine mammals of North America. J. Wildl. Dis. 37: 89-100. [Medline] [CrossRef]

28. Nymo, I. H., Tryland, M., Frie, A. K., Haug, T., Foster, G., Rødven, R. and Godfroid, J. 2013. Age-dependent prevalence of anti-Brucella antibodies in hooded seals Cystophora cristata. Dis. Aquat. Organ. 106: 187-196. [Medline] [CrossRef]

29. Nymo, I. H., Rødven, R., Beckmen, K., Larsen, A. K., Tryland, M., Quakenbush, L. and Godfroid, J. 2018. Brucella antibodies in Alaskan true seals and eared seals -two different stories. Front. Vet. Sci. 5: 8. [Medline] [CrossRef]

30. O'Corry-Crowe. 2017. Beluga whale. pp. 93-96. In: Encyclopedia of Marine Mammals, 3rd ed. (Wursig, B., Thewissen, J. G. M. and Kovacs, M. eds.), Academic Press, San Diego. 
31. Ohishi, K., Ninomiya, A., Kida, H., Park, C. H., Maruyama, T., Arai, T., Katsumata, E., Tobayama, T., Boltunov, A. N., Khuraskin, L. S. and Miyazaki, N. 2002. Serological evidence of transmission of human influenza A and B viruses to Caspian seals (Phoca caspica). Microbiol. Immunol. 46: 639-644. [Medline] [CrossRef]

32. Ohishi, K., Zenitani, R., Bando, T., Goto, Y., Uchida, K., Maruyama, T., Yamamoto, S., Miyazaki, N. and Fujise, Y. 2003. Pathological and serological evidence of Brucella-infection in baleen whales (Mysticeti) in the western North Pacific. Comp. Immunol. Microbiol. Infect. Dis. 26: 125-136. [Medline] [CrossRef]

33. Ohishi, K., Kishida, N., Ninomiya, A., Kida, H., Takada, Y., Miyazaki, N., Boltunov, A. N. and Maruyama, T. 2004. Antibodies to human-related H3 influenza A virus in Baikal seals (Phoca sibirica) and ringed seals (Phoca hispida) in Russia. Microbiol. Immunol. 48: 905-909. [Medline] [CrossRef]

34. Ohishi, K., Takishita, K., Kawato, M., Zenitani, R., Bando, T., Fujise, Y., Goto, Y., Yamamoto, S. and Maruyama, T. 2004. Molecular evidence of new variant Brucella in North Pacific common minke whales. Microbes Infect. 6: 1199-1204. [Medline] [CrossRef]

35. Ohishi, K., Takishita, K., Kawato, M., Zenitani, R., Bando, T., Fujise, Y., Goto, Y., Yamamoto, S. and Maruyama, T. 2005. Chimeric structure of omp2 of Brucella from Pacific common minke whales (Balaenoptera acutorostrata). Microbiol. Immunol. 49: 789-793. [Medline] [CrossRef]

36. Ohishi, K., Bando, T., Abe, E., Kawai, Y., Fujise, Y. and Maruyama, T. 2016. Long-term and large-scale epidemiology of Brucella infection in baleen whales and sperm whales in the western North Pacific and Antarctic Oceans. J. Vet. Med. Sci. 78: 1457-1464. [Medline] [CrossRef]

37. Ross, H. M., Jahans, K. L., MacMillan, A. P., Reid, R. J., Thompson, P. M. and Foster, G. 1996. Brucella species infection in North Sea seal and cetacean populations. Vet. Rec. 138: 647-648. [Medline] [CrossRef]

38. Sasaki, H., Numachi, K. and Grachev, M. A. 2003. The origin and genetic relationships of the Baikal seal, Phoca sibirica, by restriction analysis of mitochondrial DNA. Zool. Sci. 20: 1417-1422. [Medline] [CrossRef]

39. Scholz, H. C., Hubalek, Z., Sedlácek, I., Vergnaud, G., Tomaso, H., Al Dahouk, S., Melzer, F., Kämpfer, P., Neubauer, H., Cloeckaert, A., Maquart, M., Zygmunt, M. S., Whatmore, A. M., Falsen, E., Bahn, P., Göllner, C., Pfeffer, M., Huber, B., Busse, H. J. and Nöckler, K. 2008. Brucella microti sp. nov., isolated from the common vole Microtus arvalis. Int. J. Syst. Evol. Microbiol. 58: 375-382. [Medline] [CrossRef]

40. Scholz, H. C., Nöckler, K., Göllner, C., Bahn, P., Vergnaud, G., Tomaso, H., Al Dahouk, S., Kämpfer, P., Cloeckaert, A., Maquart, M., Zygmunt, M. S., Whatmore, A. M., Pfeffer, M., Huber, B., Busse, H. J. and De, B. K. 2010. Brucella inopinata sp. nov., isolated from a breast implant infection. Int. J. Syst. Evol. Microbiol. 60: 801-808. [Medline] [CrossRef]

41. Tryland, M., Sørensen, K. K. and Godfroid, J. 2005. Prevalence of Brucella pinnipediae in healthy hooded seals (Cystophora cristata) from the North Atlantic Ocean and ringed seals (Phoca hispida) from Svalbard. Vet. Microbiol. 105: 103-111. [Medline] [CrossRef]

42. Whatmore, A. M., Davison, N., Cloeckaert, A., Al Dahouk, S., Zygmunt, M. S., Brew, S. D., Perrett, L. L., Koylass, M. S., Vergnaud, G., Quance, C., Scholz, H. C., Dick, E. J. Jr., Hubbard, G. and Schlabritz-Loutsevitch, N. E. 2014. Brucella papionis sp. nov., isolated from baboons (Papio spp.). Int. J. Syst. Evol. Microbiol. 64: 4120-4128. [Medline] [CrossRef]

43. Zygmunt, M. S., Blasco, J. M., Letesson, J. J., Cloeckaert, A. and Moriyón, I. 2009. DNA polymorphism analysis of Brucella lipopolysaccharide genes reveals marked differences in O-polysaccharide biosynthetic genes between smooth and rough Brucella species and novel species-specific markers. BMC Microbiol. 9: 92. [Medline] [CrossRef] 